\title{
THE ROLE OF TOURISM IN THE INDONESIAN ECONOMY
}

\section{(PERAN SEKTOR PARIWISATA DALAM PEREKONOMIAN INDONESIA)}

\author{
Marinda Asih Ramadhaniah \\ Badan Perencanaan Pembangunan Daerah Provinsi Kalimantan Timur \\ Jl. Kesuma Bangsa No. 2 Samarinda \\ Email: marinda.asih.r@gmail.com
}

Received: June $6^{\text {th }} 2020$; Revised: June 19 ${ }^{\text {th }} 2020$; Approved: June $22^{\text {nd }} 2020$

\begin{abstract}
ABSTRAK
Studi ini mengkaji peran pariwisata terhadap ekonomi di Indonesia untuk menguji apakah pariwisata memberikan dampak positif kepada pertumbuhan ekonomi, baik jangka pendek (short term) maupun jangka panjang (long term) dan sebagai kontribusi literature atas perdebatan yang masih berjalan mengenai hipotesis pertumbuhan yang bertumpu pada pariwisata (Tourism-led Growth Hypothesis). Penelitian ini mengivestigasi hubungan antara jumlah turis internasional yang datang ke Indonesia, GDP harga konstan, dan nilai tukar efektif rupiah dengan menggunakan data triwulanan dalam periode 2000 - 2014 di Indonesia. Hasil penelitian dengan menggunakan tes kointegrasi Engle Granger dan Johansen menunjukkan bahwa terdapat hubungan jangka panjang (long term) diantara variabel. Namun, pada hasil tes hubungan kausalitas, Vector Error Correction (VEC), hipotesis pertumbuhan bertumpu pada pariwisata tidak terbukti di Indonesia. Hubungan yang terjadi ialah pariwisata bertumpu pada pertumbuhan.
\end{abstract}

Kata kunci: Pariwisata, Vector Error Correction Model, Granger Causality, Pertumbuhan Ekonomi, Kausalitas

\begin{abstract}
This study investigated the role of tourism in the Indonesian economy to find whether tourism makes a positive impact on economic growth in Indonesia, both in short-run and long-run, and thus to contribute evidence to the ongoing debate about the Tourism-Led Growth (TLG) hypothesis. This study examined the relationships between international tourist arrivals, the real GDP, and the real effective exchange rate in the case of Indonesia in the quarterly data from 2000:Q1-2014:Q4. Using the co-integration test both in Engle Granger and Johansen Cointegration tests, it was found that long run relationships among variables exist. However, when the Vector Error Correction (VEC) for testing the causality was applied, Tourism-Led Growth (TLG) in the case of Indonesia does not exist. The relationship is unidirectional from output-led tourism
\end{abstract}

Keywords: Tourism, Vector Error Correction Model, Granger Causality, Economic Growth

\section{INTRODUCTION}

Before the 1990s, tourism did not get much attention from researchers. But, because of the surprising performance of international tourism, as 2014, the fifth consecutive year of global robust growth in tourism above the long term average since the financial crisis of 2009, now tourism is the one of main sectors being considered by researchers for its contribution to the economy. This is especially the case for developing countries which seek an alternative sector to maintain a sustainable economy. The important role of tourism on the economy is now accepted by economists and policy makers. This fact is strongly supported by the United 
Nations in the UN Conference on Trade and Development 2010 which states that tourism has begun to be an important sector to strengthen not only the economy of a country but also its social development. Tourism increases the number of the employment absorption with its job opportunities, develops rural areas with its tourism promotion, and contributes to decreasing the poverty rate.

Recently with the growth of tourism, researchers have investigated it as an economic phenomenon. One formulation to explain the economic impact of tourism is the Tourism LedGrowth (TLG) hypothesis. This study investigated whether this hypothesis would prove to be correct in Indonesia. Indonesia is a growing tourist destination and is an excellent example of a developing nation with rich natural resources in the form of both products and scenery. The tourism sector has grown and already is a significant source of export revenue for Indonesia. In 2013, the tourism sector was fourth in the foreign exchange earnings rank of Indonesia and in 2006-2014. Indonesia was in the top five most visited East Asian travel destinations, based on the number of international tourist arrivals. If the TLG hypothesis were shown to be valid in Indonesia, that knowledge could help increase growth through policy decision which is still below the pre-1997 crisis level.

The Tourism Led-Growth (TLG) hypothesis has been researched in many studies, but the findings have varied. The case of Indonesia has been largely absent so far from the research. Most studies that have paid attention to East Asian Economies are in Korea, Taiwan, Malaysia, and Singapore. However, limited research has been done on the contribution of the tourism sector to other economic sectors such as industries, trades, services, farming, and so on in Indonesia. For future projection of Indonesia's economy, it is important to know further the relationship between tourism and economic growth.

Cortéz-Jiménez et al. (2009) argued that until recently, much of literature which focused on the product exports has put much attention on primary sectors and manufacturing sector such as agriculture, coal, and oil. The researchers argued that each category of export products has different effects on economic growth. But, the services sector's contribution to the economic growth has been ignored. Tourism, international tourism, as part of the service sector, might be considered as an export in a non-traditional way because tourism is a simple way to earn receipts and consumption, differently from other traditional export products.

According to Cortéz-Jiménez et al. (2009), in particular, the investigation of the relationship between tourism and economic growth in the long term can provide essential information for formulating and planning strategic policy through demonstrating theoretical assumptions in the regional and national level of analysis. They argued convincingly that in the tourism literature, there are two main streams of thought stemming from the so-called Export-Led Growth (ELG) hypothesis. They cited the Nowak et al. (2007) study stating that tourism receipts can increase the volume of inputs and in the end can achieve the economic growth. This economic relationship is known as Tourism Capital Imports to Growth (TKIG). The TKIG hypothesis has been empirically supported for the case of Spain. The second main hypothesis is the Tourism-Led Growth (TLG) hypothesis which postulates that by expanding international tourism as a non-traditional export the economic growth of countries can be not only generated but also explained better how tourism affects the economy in a fundamental way.

The results for the tourism-led growth (TLG) hypothesis have been mixed. Some of them found a positive relationship, but others found that tourism has no impact on the growth. The differing results are probably because of the different variables used, the data which have been used, and the methodology which has been used to analyse the data. It is clear that further research is needed and much research is continuing to clarify these results, including this present study. 
Table 1. A Selection of Empirical Studies on the Tourism-Led Growth Hypothesis

\begin{tabular}{|c|c|c|c|c|c|}
\hline Author & Data & $\begin{array}{c}\text { Dependent } \\
\text { Variable }\end{array}$ & Methodology & Independent Variable & Result \\
\hline $\begin{array}{l}\text { Balaguer \& } \\
\text { Cantavella- } \\
\text { Jorda (2002) }\end{array}$ & $\begin{array}{l}\text { Spain } \\
\text { 1975:Q1- } \\
\text { 1997:Q1 }\end{array}$ & Real GDP & $\begin{array}{l}\text { Johansen-Juselius } \\
\text { Cointegration } \\
\text { and Causality } \\
\text { tests (VECM) }\end{array}$ & $\begin{array}{l}\text { International tourism } \\
\text { earnings in real terms } \\
\& \text { Real Effective } \\
\text { Exchange Rate }\end{array}$ & $\begin{array}{c}\text { Tourism } \rightarrow \\
\text { Growth }\end{array}$ \\
\hline $\begin{array}{l}\text { Dritsakis } \\
(2004)\end{array}$ & $\begin{array}{l}\text { Greece } \\
\text { 1960:Q1- } \\
\text { 2000:Q4 }\end{array}$ & Real GDP & $\begin{array}{l}\text { Johansen } \\
\text { Cointegration } \\
\text { and Causality } \\
\text { tests (VECM) }\end{array}$ & $\begin{array}{l}\text { International tourism } \\
\text { earnings in real terms } \\
\& \text { Real Effective } \\
\text { Exchange Rate }\end{array}$ & $\begin{array}{c}\text { Tourism } \leftrightarrow \\
\text { Growth }\end{array}$ \\
\hline $\begin{array}{l}\text { Lorde, T. et al } \\
\qquad(2011)\end{array}$ & $\begin{array}{l}\text { Barbados } \\
\text { 1974:Q1- } \\
\text { 2004:Q4 }\end{array}$ & $\begin{array}{l}\text { Real GDP } \\
\text { and Real } \\
\text { GDP per } \\
\text { capita }\end{array}$ & $\begin{array}{l}\text { Johansen-Juselius } \\
\text { Cointegration } \\
\text { and Causality } \\
\text { tests (VECM) }\end{array}$ & $\begin{array}{c}\text { International Tourist } \\
\text { Arrivals \& Real } \\
\text { Exchange Rate, } \\
\text { Seasonal Dummy }\end{array}$ & $\begin{array}{c}\text { Growth (Real } \\
\text { GDP) } \rightarrow \\
\text { Tourism; } \\
\text { Tourism (Real } \\
\text { GDP per } \\
\text { capita) } \leftrightarrow \\
\text { Growth }\end{array}$ \\
\hline $\begin{array}{c}\text { Kim et al. } \\
(2005)\end{array}$ & $\begin{array}{l}\text { Taiwan } \\
\text { 1971:Q1- } \\
\text { 2003:Q2 }\end{array}$ & Real GDP & $\begin{array}{l}\text { Johansen-Juselius } \\
\text { and Granger } \\
\text { Causality tests } \\
\text { (VAR) }\end{array}$ & Total Tourist Arrivals & $\begin{array}{c}\text { Tourism } \leftrightarrow \\
\text { Growth }\end{array}$ \\
\hline $\begin{array}{l}\text { Lean \& Tang } \\
\text { (2010) }\end{array}$ & $\begin{array}{l}\text { Malaysia } \\
\text { 1989:M1- } \\
\text { 2009:M2 }\end{array}$ & Real GDP & $\begin{array}{l}\text { Toda-Yamamoto- } \\
\text { Dolado- } \\
\text { Lütkepohl- } \\
\text { MWALD }\end{array}$ & $\begin{array}{l}\text { Total international } \\
\text { visitor arrivals }\end{array}$ & $\begin{array}{c}\text { Tourism } \leftrightarrow \\
\text { Growth }\end{array}$ \\
\hline $\begin{array}{l}\text { Katircioglu } \\
\text { (2011) }\end{array}$ & $\begin{array}{l}\text { Singapore } \\
1960-2007\end{array}$ & Real GDP & $\begin{array}{l}\text { Cointegration- } \\
\text { ARDL-Granger } \\
\text { Causality (VECM) }\end{array}$ & $\begin{array}{l}\text { Total number of } \\
\text { international tourist } \\
\text { visiting and } \\
\text { accommodating in } \\
\text { Malaysia \& Real } \\
\text { Effective Exchange } \\
\text { rate index }\end{array}$ & $\begin{array}{c}\text { Tourism } \rightarrow \\
\text { Growth }\end{array}$ \\
\hline Oh (2005) & $\begin{array}{c}\text { Korea } \\
\text { 1975:Q1- } \\
\text { 2001:Q1 }\end{array}$ & Real GDP & $\begin{array}{l}\text { Johansen-Juselius } \\
\text { and Granger } \\
\text { Causality tests } \\
\text { (VAR) }\end{array}$ & $\begin{array}{l}\text { Real Aggregate } \\
\text { Tourism Receipts } \\
\text { adjusted by CPI }\end{array}$ & $\begin{array}{c}\text { Growth } \rightarrow \\
\text { Tourism }\end{array}$ \\
\hline $\begin{array}{l}\text { Tang \& Jang } \\
\text { (2009) }\end{array}$ & $\begin{array}{l}\text { United } \\
\text { States } \\
\text { 1981:Q1- } \\
\text { 2005:Q4 }\end{array}$ & GDP & $\begin{array}{l}\text { Johansen-Juselius } \\
\text { Cointegration } \\
\text { and Causality } \\
\text { tests (VECM) }\end{array}$ & $\begin{array}{l}\text { Aggregate industry } \\
\text { sales revenue (four } \\
\text { tourism related } \\
\text { industries) }\end{array}$ & $\begin{array}{l}\text { Growth } \rightarrow \\
\text { Tourism }\end{array}$ \\
\hline $\begin{array}{l}\text { Cortez- } \\
\text { Jimenez et al. } \\
\text { (2011) }\end{array}$ & $\begin{array}{c}\text { Tunisia } \\
(1975-2007)\end{array}$ & Real GDP & $\begin{array}{l}\text { Johansen-Juselius } \\
\text { Cointegration } \\
\text { and Causality } \\
\text { tests (VECM) }\end{array}$ & $\begin{array}{c}\text { Real international } \\
\text { tourism receipts (TOU) } \\
\text { and real } \\
\text { imports of industrial } \\
\text { machinery (IMP) }\end{array}$ & $\begin{array}{l}\text { Growth } \rightarrow \\
\text { Tourism }\end{array}$ \\
\hline Tang (2011) & $\begin{array}{l}\text { Malaysia } \\
\text { 1995:M1- } \\
\text { 2009:M2 }\end{array}$ & Real GDP & $\begin{array}{l}\text { ECM-based t- } \\
\text { test; Granger } \\
\text { causality (VECM) }\end{array}$ & $\begin{array}{c}\text { International visitor } \\
\text { arrivals to Malaysia } \\
\text { from } \\
\text { different countries } \\
\text { adjusted by CPI }\end{array}$ & $\begin{array}{c}\text { Growth } \rightarrow \\
\text { Tourism }\end{array}$ \\
\hline
\end{tabular}

Notes: $\rightarrow$ refer to uni-directional causality

$\leftrightarrow$ refer to bidirectional causality

VECM represents vector error correction model; VAR represents vector autoregression; MWALD denotes modified Wald; ARDL represents autoregressive distributed lag.

Source: Compiled by Author 
Pablo-Romero \& Molina (2013) stated that the first study which investigated the relationship between tourism and growth from an empirical point of view is Ghali (1976) and Lanza \& Pigliaru (2000), while the first study that analysed the tourism-led growth hypothesis is Balaguer \& Cantavella-Jordá (2002). So far, the results of the TLG hypothesis in the different case studies have yielded various results. In Akinboade \& Braimoh (2010), the research of Balaguer \& Cantavella-Jordá (2002), Kim et al. (2006), Martin et al. (2004) and Marin (1992) all showed that tourism expansion is adequate for increasing the economic growth in medium-income countries. On the other hand, Oh (2005) failed to support the TLG hypothesis about the long run relationship between tourism and economic growth in the case of Korea. As cited in Oh, there are numerous studies that failed to support this hypothesis such as Darrat (1986), Hsiao (1987), and Dodaro (1993). Furthermore, in Oh's research, he recommended that it would be valuable to examine the question that whether tourism has contributed positively to the economy as it is commonly belief or not. Furthermore, this study summarised the selections published journal articles, especially the research which have similar variables and analysis methodology approach that are relevant to this study.

To the best of our knowledge, during the period 2000 to 2016, only Nizar (2015) has investigated the validity of the tourism-led growth hypothesis in Indonesia. He used the Vector Autoregressive (VAR) model to analyse the causal relationship between the growth of tourism and economic growth on quarterly data from 1995-2009. He used tourism receipts as the proxy for the tourism growth adjusted by the consumer price index. The study supported the TLG hypothesis and found a reciprocal causal hypothesis between tourism and economic growth. In the present study, further investigation into the case of Indonesia will be conducted. However, unlike Nizar, this study will use different variables and methodology approach. This study will use international tourist arrivals as a proxy for the tourism expansion, real GDP as the proxy for economic growth, and include the real effective exchange rate in the model. The Engle-Granger test and Johansen cointegration test will be used to examine a cointegration relation among variables. Causality test and error correction model (ECM) will be used to analyse the relationship between tourism and economic growth both in the long run and short run. The result in this study is expected to strengthen the previous study of Nizar (2015) that there is a reciprocal relationship between tourism and economic growth in the case of Indonesia not only in the short run but also in the long run.

\section{METHODOLOGY}

There are many empirical studies which have been conducted to analyse the engine of growth. One studies which stimulated the interest of researchers in looking at the role of tourism as an engine driving economic growth was the study in 2002 by Balaguer and Cantavella-Jordá (as cited in Tang \& Abosedra, 2016). The bivariate modelling approach to analyse the tourism-led growth hypothesis was used by some researchers, and other used a multivariate modelling approach to analyse the hypothesis, due to the fact that the omitted variable bias in the bi-variate model might cause spurious regression results (Tang \& Abosedra, 2016).

Balaguer and Cantavella-Jordá (2002) argued that for long run analysis between tourism and economic growth, the number of variables should be held to a minimum because the more variables included in the model the higher the likelihood to obtain more than one relationship in the long run. In the previous studies, the variables employed as a proxy for tourism expansion are varied. Some studies have used the tourism receipts as the variable for tourism and others have used international tourist arrivals. Similar to the proxy for tourism, previous studies have also used different variables as proxies for economic growth. But, the most commonly used variables are real GDP and real GDP per capita.

This study uses international tourist arrivals as the proxy for tourism because of limited availability and unrealibity of the data in Indonesia, so tourism receipts were excluded, real GDP as a proxy for economic growth, and real effective exchange rate as the important 
control variable. This study investigates the linkage among tourism, economic growth, and the effective exchange rate for both long-run equilibrium and short-run relationships. This study used quarterly data for Indonesia. The time range is 2000:Q1-2014:Q4. All variables are in natural logarithm form. The data specifications and sources used in the research are as follows in Table 2:

Table 2. Variables and data

\begin{tabular}{|c|c|c|}
\hline Variable & Data & Measurement Unit \\
\hline $\operatorname{lnGDP}$ & $\begin{array}{l}\text { Gross Domestic Products of } \\
\text { Indonesia }\end{array}$ & $\begin{array}{l}\text { Constant Price based on } 2000 \text { year price } \\
\text { (million US\$) }\end{array}$ \\
\hline InTA & International Tourist Arrivals & Total international tourist arrivals \\
\hline InREER & $\begin{array}{l}\text { Real Effective Exchange Rate of } \\
\text { Indonesia } \\
\text { (CPI-Based) }\end{array}$ & $\begin{array}{l}\text { The REER calculated as: } \\
\qquad R E E R_{t}=\frac{N E E R_{t} x C P I_{t}}{C P I_{t}^{(f o r e i g n)}} \\
\text { - } \quad R E E R \text { is the real effective exchange rate of the Indonesia } \\
\text { against a basket of currencies of trading partners (138 } \\
\text { countries), } \\
\text { - } C P I \text { is the consumer price index of the country under } \\
\text { study, } \\
\text { - } \quad \text { CEER is the nominal effective exchange rate of the } \\
\text { country under study } \\
\text { The quarterly data is the average of the monthly data }\end{array}$ \\
\hline
\end{tabular}

Notes: Data for the GDP and the international tourist arrivals are compiled from Statistics Indonesia (BPS). Data for the GDP is retrieved on the http://www.bps.go.id/linkTabelStatis/view/id/1206 on March, 20, 2016, data for international tourist arrivals is compiled from Publication of Statistik Kunjungan Wisatawan Mancanegara 2008 and http://www.bps.go.id/linkTableDinamis/view/id/807 which retrieved on January, 25, 2016 and data for the real effective exchange rate of Indonesia (CPI-Based) is compiled from Bruegel Dataset which retrieved on http://bruegel.org/publications/datasets/real-effective-exchange-rates-for-178-countries-anew-database/ on May, 9, 2016

Since quarterly data are used, this current research initially specified a model following Katircioğlu (2011) as:

$$
\operatorname{lngdp_{t}}=a_{0}+a_{2} \operatorname{lnta}_{t}+a_{3} \text { lnreer }_{t}+e_{t}
$$

where

lngdp = natural logarithm of real gross domestic products

lnta = natural logarithm of international tourist arrivals

lnreer $=$ natural logarithm of real effective exchange rate

The purpose of using natural logarithm form is to see the elasticity effect of the independent variables on the dependent variable in the model. Thus, to simplify the interpretation of the results, the model uses the coefficients of each variable in the model as the units of measurements.

As its analysis methodology, the data was tested for unit root test and cointegration tests. A unit root test was used to check the stationarity of the data series. Based on Pratiwi (2010), one method that can be applied is Augmented-Dickey Fuller (ADF) test. Another test that is often used to examine the stationarity of data is Phillips-Perron (PP) test. Generally, these test was the same procedure as the ADF test. Thus, this current study will apply both of the tests to test the stationary of the data series. After reaching the stationary data, the next step is to investigate the appropriate lag length. There are many criteria that used to examine the optimum lag $p$ such as the minimum Akaike Information Criterion (AIC), Schwarz 
Information Criterion (SIC), Final Prediction Error (FPE), Likelihood Ratio (LR), and HananQuinn Information Criterion (HQ). Enders (2010) stated that most researchers begin with a lag length of approximately $T^{1 / 3}$, where $\mathrm{T}$ is the number of observation. This study used all of those criteria to determine the optimum lag length.

\section{RESULT AND DISCUSSION}

The first step was to investigate the stationarity using unit root test properties by applying the Augmented Dickey-Fuller (ADF) Test and Phillips-Perron (PP) Test. From the results of the unit root test, the result of the ADF test and the PP test were different. However, both ADF and PP tests showed that all of the variables were stationary at the first difference with the intercept model (Table 3). Since the ADF and PP test showed different results, this study employed Kwiatkowski-Phillips-Schmidt-Shin (KPSS) test to decide whether the $1^{\text {st }}$ difference or $2^{\text {nd }}$ difference with the intercept model or the intercept and trend model should be used in the calculation. Therefore, based on the results in table 4, it can be concluded that real GDP, international tourist arrivals, and REER are integrated of order one, I(1), at the confidence level of $95 \%$.

Table 3. ADF and PP Tests for Unit Root

\begin{tabular}{|c|c|c|c|c|c|c|c|c|}
\hline \multirow[b]{2}{*}{ Variable } & \multicolumn{3}{|c|}{ None } & \multicolumn{2}{|c|}{ With Intercept } & \multicolumn{3}{|c|}{ With Intercept and Trend } \\
\hline & Level & $\begin{array}{c}\text { First } \\
\text { Difference }\end{array}$ & $\begin{array}{c}\text { Second } \\
\text { Difference }\end{array}$ & Level & $\begin{array}{c}\text { First } \\
\text { Difference }\end{array}$ & Level & $\begin{array}{c}\text { First } \\
\text { Difference }\end{array}$ & $\begin{array}{c}\text { Second } \\
\text { Difference }\end{array}$ \\
\hline \multicolumn{9}{|c|}{ Augmented Dickey Fuller (ADF) Test } \\
\hline $\operatorname{lnGDP}$ & 3.362 & -0.387 & & 1.103 & $-3.287^{* *}$ & -2.966 & $-3.484^{*}$ & $-40.914 * * *$ \\
\hline InTA & 1.514 & $-3.551 * * *$ & $-41.617 * * *$ & 0.160 & $-8.560 * * *$ & $-3.656 * *$ & $-8.943 * * *$ & \\
\hline InREER & 0.570 & $-7.415 * * *$ & & -1.903 & $-7.435 * * *$ & -2.271 & $-7.441 * * *$ & \\
\hline \multicolumn{9}{|c|}{ Phillips-Perron (PP) Test } \\
\hline InGDP & 16.245 & $-7.768 * * *$ & & 0.938 & $-20.23 * * *$ & $-6.259 * * *$ & & \\
\hline $\operatorname{lnTA}$ & 2.285 & $-9.817 * * *$ & & -0.859 & $-13.20 * * *$ & $-3.669 * * *$ & & \\
\hline InREER & 0.542 & $-7.415^{* * *}$ & & -1.597 & $-7.438 * * *$ & -2.544 & $-7.449 * * *$ & \\
\hline
\end{tabular}

Note: Here GDP represents real GDP, TA is total international tourist arrivals to Indonesia, and REER is real effective exchange rate index; ADF test is determined by SIC set to a maximum lag of ten and PP test represents Newey-West Bandwith as determined by Barlett-Kernel; *,**,*** denotes rejection of the null hypothesis at the $1 \%, 5 \%$, and $10 \%$ levels, respectively. Tests for unit roots have been carried out in E-VIEWS 9.0.

Source: Author calculation.

Table 4. Kwiatkowski-Phillips-Schmidt-Shin (KPSS) Test for Unit Root

\begin{tabular}{lccccc}
\hline \multirow{2}{*}{ Variable } & \multicolumn{2}{c}{ With Intercept } & \multicolumn{3}{c}{ With Intercept and Trend } \\
\cline { 2 - 6 } & Level & $\begin{array}{c}\text { First } \\
\text { Difference }\end{array}$ & Level & $\begin{array}{c}\text { First } \\
\text { Difference }\end{array}$ & $\begin{array}{c}\text { Second } \\
\text { Difference }\end{array}$ \\
\cline { 2 - 6 } & $0.964^{* * *}$ & 0.307 & $0.249^{* * *}$ & $0.224^{* * *}$ & $0.266^{* * *}$ \\
InGDP & $0.864^{* * *}$ & 0.253 & $0.227^{* * *}$ & $0.168^{*}$ & \\
InTA & $0.743^{* * *}$ & 0.066 & $0.129^{*}$ & 0.049 & \\
\hline
\end{tabular}

Note: the null hypothesis is that the data are stationary; KPSS test represents Newey-West Bandwith as determined by Barlett-Kernel; *, **,*** denotes rejection of the null hypothesis at the $1 \%, 5 \%$, and $10 \%$ levels, respectively.

Source: Author Calculation

Given the result of the test for stationarity of the variables in the previous section, it is important to examine the cointegration among the variables in order to know whether these variables have a long-run relationship. As stated in the previous chapter, this study employed the Engle-Granger procedures. The stationarity of residuals from the OLS regression was 
tested by applying the ADF test. Based on the ADF test results in Table 5, it was clear that there is cointegration among the variables. At $1 \%$ level of significance, the null hypothesis which proposes the existence of a unit root on residual series was rejected. Furthermore, this study found a long-run equilibrium relationship among variables.

Table 5. ADF Unit Root Test for Residuals

\begin{tabular}{ll}
\hline \multirow{2}{*}{ Variable } & With Intercept \\
\cline { 2 - 2 } & Level \\
\hline Residuals & $-4.701^{* * *}$
\end{tabular}

Note: Here residuals represents the residuals from the OLS regression; ADF test is determined by SIC set to a maximum lag of ten; *,**, *** denotes rejection of the null hypothesis at the $1 \%, 5 \%$, and $10 \%$ levels, respectively. Tests for unit roots have been carried out in E-VIEWS 9.0.

Source: Author calculation

This study also employed the Johansen cointegration test to support the Engle-Granger results. The step before applying the Johansen cointegration test is to examine the appropriate lag length. Enders (2010) stated that most researchers begin with a lag length of approximately $T^{1 / 3}$, where $\mathrm{T}$ is the number of observations. Through this formula, with 60 observations, the appropriate number of lags in this study is $60^{1 / 3}=3.9 \approx 4$ lag. The minimum Akaike Information Criterion (AIC), Schwarz Information Criterion (SIC), Final Prediction Error (FPE), Likelihood Ratio (LR), and Hanan-Quinn Information Criterion (HQ) were also used to examine the optimum lag $p$. Thus, the results of lag length criteria test in Table 6 indicated that the appropriate number of lags is 4 lags.

Table 6. Lag Order Selection Criteria

\begin{tabular}{ccccccc}
\hline Lag & LogL & LR & FPE & AIC & SC & HQ \\
\hline 0 & 122.7672 & NA & $2.79 \mathrm{e}-06$ & -4.277399 & -4.168898 & -4.235333 \\
1 & 296.9178 & 323.4226 & $7.65 \mathrm{e}-09$ & -10.17564 & -9.741632 & -10.00737 \\
2 & 309.3944 & 21.83400 & $6.78 \mathrm{e}-09$ & -10.29980 & -9.540292 & -10.00534 \\
3 & 321.0109 & 19.08429 & $6.22 \mathrm{e}-09$ & -10.39325 & -9.308236 & -9.972590 \\
4 & 378.8435 & $88.81443^{*}$ & $1.10 \mathrm{e}-09^{*}$ & $-12.13727^{*}$ & $-10.72676^{*}$ & $-11.59042^{*}$ \\
\hline
\end{tabular}

Note: * indicates lag order selected by the criterion; LR: sequential modified LR test statistic (each test at 5\% level); FPE: Final prediction error; AIC: Akaike information criterion; SC: Schwarz information criterion; HQ: Hannan-Quinn information criterion. Tests for unit roots have been carried out in E-VIEWS 9.

The results of the Johansen cointegration test are presented in Table 7. Two likelihood ratio tests are employed in this procedure, the trace statistic and the maximum eigenvalue statistics. From the results of Table 7, the trace and maximum eigenvalue statistics indicate mixed results for every model. In Model 2, both the trace and maximum eigenvalue statistics show that there is one cointegrating equation at $5 \%$ level of significance. Similar to Model 2, Model 3 shows that there exists at least one cointegrating equation both in trace and maximum eigenvalue but with different levels of significance. In contrast, in Model 4, the trace test shows that there are at least two co-integrating equations at $10 \%$ level of significance, but the maximum eigenvalue statistic shows that only one co-integrating equation in the model. However, these results support the findings of the Engle-Granger cointegration test. It is concluded that there is a long-run equilibrium relationship between real GDP, tourism, and real effective exchange rate in Indonesia. 
Table 7. Johansen Cointegration Test Results

\begin{tabular}{|c|c|c|c|c|c|c|c|}
\hline \multirow[t]{2}{*}{ Null Hypothesis } & \multirow[t]{2}{*}{$\begin{array}{l}\text { Alternative } \\
\text { Hypothesis }\end{array}$} & \multicolumn{2}{|c|}{$\begin{array}{c}\text { Model } 2 \\
\text { (Intercept in CE \& no } \\
\text { intercept or trend in } \\
\text { VAR) }\end{array}$} & \multicolumn{2}{|c|}{$\begin{array}{c}\text { Model } 3 \\
\text { (Intercept in CE and } \\
\text { VAR \& no trend in CE } \\
\text { \& VAR) }\end{array}$} & \multicolumn{2}{|c|}{$\begin{array}{c}\text { Model } 4 \\
\text { (Intercept in CE and } \\
\text { VAR \& No trend in } \\
\text { VAR) }\end{array}$} \\
\hline & & $\begin{array}{c}\text { Test } \\
\text { Statistics }\end{array}$ & P-Values & $\begin{array}{c}\text { Test } \\
\text { Statistics }\end{array}$ & P-Values & $\begin{array}{c}\text { Test } \\
\text { Statistics }\end{array}$ & P-Values \\
\hline \multicolumn{8}{|l|}{ Trace Test } \\
\hline$r=0$ & $r \leq 0$ & $40.798^{* *}$ & 0.0112 & $29.634^{*}$ & 0.0522 & $48.743 * *$ & 0.0118 \\
\hline$r=1$ & $r \leq 1$ & 17.646 & 0.1102 & 7.790 & 0.4881 & $23.609 *$ & 0.0932 \\
\hline$r=2$ & $r \leq 2$ & 6.313 & 0.1679 & 0.381 & 0.5372 & 6.386 & 0.4129 \\
\hline \multicolumn{8}{|l|}{ Max Eigenvalue Test } \\
\hline$r=0$ & $r=1$ & $23.152 * *$ & 0.0380 & $0.328 * *$ & 0.0397 & $25.823 *$ & 0.0615 \\
\hline$r=1$ & $r=2$ & 11.333 & 0.2281 & 0.126 & 0.4419 & 19.387 & 0.1003 \\
\hline$r=2$ & $r=3$ & 3.313 & 0.1679 & 0.007 & 0.5372 & 12.518 & 0.4129 \\
\hline
\end{tabular}

Note: $*, * *, * * *$ indicate significance at the $10 \%, 5 \%, 1 \%$ levels, respectively.

Source: Author calculation

To determine the direction causality among variables, this study applied the Vector Error Correction (VEC) model results shown in Table 8. In order to choose the appropriate model to examine the short run relationship among variables, the Akaike Information Criterion determined Model 4 as the best model, while the Schwarz Criterion determined Model 3 as the best model. Therefore, this study examined both of the models for the long-run equilibrium and short-run dynamics relations.

Table 8. Akaike Information Criterion (AIC) and Schwarz Criterion Results

\begin{tabular}{ccc}
\hline The Model & $\begin{array}{c}\text { Akaike Information } \\
\text { Criterion (AIC) }\end{array}$ & $\begin{array}{c}\text { Schwarz } \\
\text { Criterion }\end{array}$ \\
\hline $\begin{array}{c}\text { Model 2 } \\
\text { (Intercept in CE \& } \begin{array}{c}\text { Moder intept or trend in VAR) } \\
\text { Model }\end{array}\end{array}$ & -11.985 & -10.415 \\
$\begin{array}{c}\text { Model 4 } \\
\text { (Intercept in CE and VAR \& no trend in CE \& VAR) } \\
\text { (Intercept in CE \& No trend in VAR) }\end{array}$ & -12.092 & -10.449 \\
\hline
\end{tabular}

Source: Author calculation

From Table 9, Model 4 shows that tourism has a positive and significant impact on the GDP. On the other hand, Models 2 and 3 show that only the real effective exchange rate has a significant long run relationship with GDP.

Based on the AI Criterion and the Schwarz Criterion of the best model, this study chose the Model 3 and Model 4 for the estimation of long-run cointegration for the GDP as presented below:

The long-run equation based on the Model 3:

$$
\begin{gathered}
\operatorname{lngdp}_{t}=-1.342+0.113 \text { lnta }_{t}+2.789 \text { lnreer }_{t}+e_{t} \\
(0.209)
\end{gathered}
$$

The long-run equation based on the Model 4:

$$
\begin{gathered}
\operatorname{lngdp_{t}}=-11.787+0.107 \text { lnta }_{t}+0.129 \text { lnreer }_{t}+0.013 \text { trend }+e_{t} \\
(\mathbf{0 . 0 3 1})
\end{gathered}
$$


Table 9. Long-run Results

\begin{tabular}{lccc}
\hline \multicolumn{3}{c}{ Dependent variable: Ingdp } \\
\hline & $\begin{array}{c}\text { Model 2 } \\
\text { (Intercept in CE \& no } \\
\text { intercept or trend in VAR) }\end{array}$ & $\begin{array}{c}\text { Model 3 } \\
\text { (Intercept in CE and VAR } \\
\text { \& no trend in CE \& VAR) }\end{array}$ & $\begin{array}{c}\text { Model 4 } \\
\text { (Intercept in CE and VAR } \\
\text { \& No trend in VAR) }\end{array}$ \\
\hline Inta & 0.028 & 0.113 & $0.107^{*}$ \\
Inreer & $(0.253)$ & $(0.209)$ & $(0.031)$ \\
& $3.188^{*}$ & $2.789^{*}$ & $0.129^{*}$ \\
Trend & $(0.544)$ & $(0.449)$ & $(0.053)$ \\
& & & $0.013^{*}$ \\
Constant & & & $(0.0007)$ \\
& -0.812 & -1.342 & -11.787 \\
\end{tabular}

Note: lngdp is natural log of real GDP, lnta is natural logarithm of international tourist arrivals, and lnreer is natural logarithm of real effective exchange rate index. Standard errors are reported in parantheses and $*$ indicate significance at the $5 \%$ levels, respectively.

Firstly, Model 4 shows that tourism has a positive and significant impact on the GDP. This result is consistent with the assumption that increasing the international tourist arrivals will lead to an increase in economic growth. This is also consistent with the research conducted by Kim et al. (2005) which states that tourism expansion has a positive impact on GDP of Taiwan. In this case, by using Model 4, if the international tourism arrivals increase by $1 \%$, the GDP will increase by $0.11 \%$. Model 3 , however, shows that tourism has no significant impact on the GDP. Secondly, as expected, the real effective exchange rate is one of the important variables which influences both international tourism and economic growth. Using Model 3, if there is an increase of $1 \%$ in real effective exchange rate index of Indonesia, GDP will increase to $2.79 \%$, while employing Model 4, if there is an increase of $1 \%$ in real effective exchange rate index of Indonesia, GDP will increase to $0.13 \%$. This result is similar to the research conducted by Katircioğlu (2011) which states that the real exchange rate has inelastic but positive coefficient to the GDP in the case of Singapore.

Although there is the existence of a cointegration relationship among the variables, it cannot be concluded that there is a causal relationship among the variables. An error correction model provides short-run dynamics that are necessary in the identification of equilibrium in the long run. If there exists a long-run relationship among the non-stationary time series variables, the residual from the long-run equilibrium relationship can be used to estimate the Error Correction Model (ECM). The error correction model in this study can be written as follows:

$$
\begin{aligned}
& \Delta \operatorname{lnGDP} P_{t}=\alpha_{1}+\alpha_{\text {lnGDP }} \hat{\mathrm{e}}_{t-1}+\sum_{i=1}^{m} \alpha_{11}(i) \Delta \operatorname{lnGDP}_{t-1}+\sum_{i=1}^{m} \alpha_{12}(i) \Delta \operatorname{lnTA}_{t-1}+ \\
& \sum_{i=1}^{m} \alpha_{13}(i) \Delta \operatorname{lnREER} \mathrm{R}_{t-1}+\varepsilon_{\text {lnGDPt }} \\
& \Delta \operatorname{lnTA}_{t}=\alpha_{2}+\alpha_{\text {lngTA }} \hat{\mathrm{e}}_{t-1}+\sum_{i=1}^{m} \alpha_{21}(i) \Delta \operatorname{lnGDP}_{t-1}+\sum_{i=1}^{m} \alpha_{22}(i) \Delta \operatorname{lnTA}_{t-1}+ \\
& \sum_{i=1}^{m} \alpha_{23}(i) \Delta \operatorname{lnREER_{t-1}}+\varepsilon_{\text {lnTAt }} \\
& \Delta \operatorname{lnREER}_{t}=\alpha_{3}+\alpha_{\text {lngER }} \hat{\mathrm{e}}_{t-1}+\sum_{i=1}^{m} \alpha_{31}(i) \Delta \operatorname{lnGDP}_{t-1}+\sum_{i=1}^{m} \alpha_{32}(i) \Delta \operatorname{lnTA}_{t-1}+ \\
& \sum_{i=1}^{m} \alpha_{33}(i) \Delta \operatorname{lnREER} \mathrm{R}_{t-1}+\varepsilon_{\text {lnERt }}
\end{aligned}
$$

where $\hat{\mathrm{e}}_{t-1}$ is the error correction term that shows the long run equilibrium, $\alpha_{\text {lnGDP }}, \alpha_{\text {lngTA }}$, $\alpha_{\text {lngER }}$ are the speed of adjustment coefficients. In these equations $\Delta \operatorname{lnGDP}_{t-1}$, $\Delta \operatorname{lnTA} A_{t-1}, \Delta \operatorname{lnER}_{t-1}$ are the short-run dynamic relationships of the models. 
Table 10. Granger Causality Tests for VECM Lag 4

\begin{tabular}{lllllll}
\hline & \multicolumn{3}{c}{ Model 3 } & \multicolumn{3}{c}{ Model 4 } \\
\cline { 2 - 7 } $\begin{array}{l}\text { Dependent } \\
\text { Variable }\end{array}$ & \multicolumn{3}{c}{ Chi square value } & \multicolumn{3}{c}{ Chi square value } \\
\cline { 2 - 7 } & $\operatorname{lnGDP}_{\mathrm{t}}$ & $\operatorname{lnTA}_{\mathrm{t}}$ & $\operatorname{lnREER}_{\mathrm{t}}$ & $\operatorname{lnGDP}_{\mathrm{t}}$ & $\operatorname{lnTA}_{\mathrm{t}}$ & $\operatorname{lnREER}_{\mathrm{t}}$ \\
\hline $\operatorname{lngDP}_{\mathrm{t}}$ & - & 4.326 & 4.865 & - & 3.321 & 3.926 \\
$\operatorname{lnTA}_{\mathrm{t}}$ & $8.275^{*}$ & - & 4.741 & $13.239 * *$ & - & 5.349 \\
$\operatorname{lnREER}_{\mathrm{t}}$ & 6.428 & 1.966 & - & 5.055 & - & $10.781^{* *}$ \\
\hline
\end{tabular}

Note: $*, * *, * * *$ indicate significance at the $10 \%, 5 \%, 1 \%$ levels, respectively.

Source: Author calculation

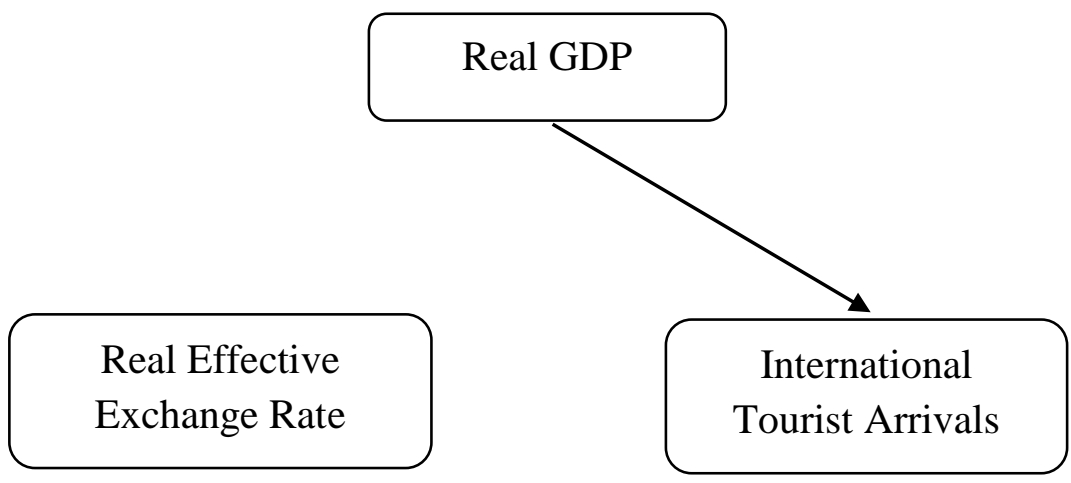

Figure 1. Granger Causality Directions for VECM in Model 3 Source: Author calculation

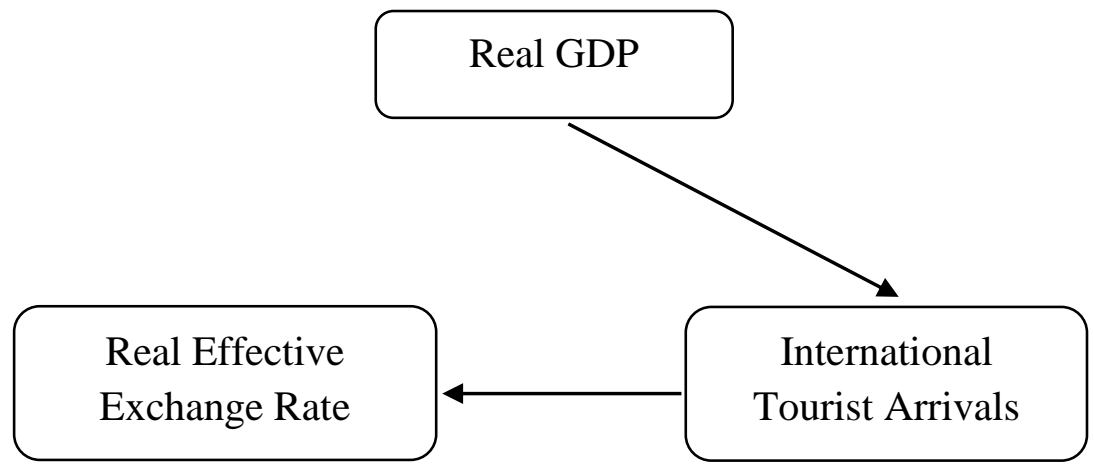

Figure 2. Granger Causality Directions for VECM in Model 4 Source: Author calculation

The result of the Granger causality test as shown in Table 10, Figure 1, and Figure 2 suggests that tourism and economic are cointegrated. However, there is only a unidirectional causality link among the variables. Both Model 3 and Model 4 showed unidirectional causality running from the real GDP to tourism. Slightly different from the long run cointegration analysis which showed the positive impact of tourism on GDP, in the short term dynamic analysis the relationship between them was not significant. This result suggests that although tourism will not immediately have a positive impact for improving economic growth in Indonesia, the impact will be seen in the long run. That is, economic development leads to international travel and increasing tourism growth. The unidirectional causality from GDP to tourism may depict the small contribution of the overall economy to tourism related industries in the short-run. Tourism could get benefit from the favourable improving the general 
economy and will offer better service and goods. It may in turn to strengthen the pull factors of the country and in the end, it will give benefit for overall economy. Thus, the Tourism-Led Growth hypothesis cannot be inferred from the Indonesian economy. Since tourism did not influence growth in the short run, there was no reciprocal feedback between the two variables. These findings on tourism and growth are in line with Oh (2005). Therefore, this study's results are not consistent with the findings for Indonesia in Nizar (2015), which supported a bidirectional relationship between these two series.

The most likely reason for the lack of unidirectional or bi-directional relationship between tourism and economic growth in the short run may be due to the fact that the international market for Indonesia's tourism is not the main source of the tourism expansion in Indonesia. Even though the international visitor arrivals have shown strong growth, with average growth $6.7 \%$ from 2000-2007, according to ILO (2009), apart from Bali possibly, Indonesia's tourism destinations depend on the increasing domestic market. Even when foreign visitor arrivals declined in 2002, 2003, and 2006, tourism conrtibuted to GDP by $8.6 \%, 9.7 \%$, and $18.6 \%$ respectively because of domestic tourists.

Another possible explanation for why tourism does not lead the economic growth is because Indonesian tourism is still at a low ratio of value added in terms of a business industry. The development of tourism in Indonesia is still not highly differentiated from the products of its South East Asian competitors (Thailand, Singapore, and Malaysia). This reason is in line with Nowak et al. (2007), as cited in Cortéz-Jiménez et al. (2009), which states that the tourism could promote economic growth in the long term through the maturing of tourism as a sector which depends on the degree of its product differentiation. As stated in ILO (2009), compared to countries such as Thailand and Malaysia, Indonesia's tourism is inadequately marketed and does not perform up to its potential. Tourism planning in Indonesia is out of date at the provincial level and at regional or local levels, little planning is done. This limits opportunities to collaborate in tourism development at the administrative level and there is a lack of basics for strategic tourism planning. As described in the introduction part, the case of Yogyakarta is an excellent example of comprehensive and successful tourism planning, and therefore, an exception.

Another problem that usually faces developing countries in tourism development is the problem of leakage of tourism. According to UNEP (n.d.), if the host country cannot supply the tourists demand such as equipment, food, and other products, they will import to fulfil those products. Therefore, the income which earned from tourism expenditures will leave the country to pay for these imports. The majority of foreign exchange earned from tourism goes to the purchase of imported goods for consumption. From 2000-2013 Indonesia's import of goods and services averaged approximately $26 \%$ of GDP. According to WTTC in Indonesia Benchmarking Report 2015, In Indonesia, a 12\% of travel \& tourism spending leaked out of the economy through imports.

Lastly, Model 4 showed the unidirectional relationship from international tourist arrivals to the real effective exchange rate index of Indonesia. The increasing number of international tourist arrivals of Indonesia induces the real effective exchange rate movement. In the empirical research on tourism, the researchers often include the real effective exchange rate in the model as a proxy to take into account the degree of openness of a given destination country. One possible way for the international tourist arrivals to be a Granger cause of real effective exchange rate is through the tourism terms of trade, where an increase in the price of imported goods, including the tourism goods, induces an appreciation of the real effective exchange rate. As the general concept of competitiveness states, if there is an appreciation of the real effective exchange rate, it will reduce the trade competitiveness of an open economy. This result is similar to the fact that tourism in Indonesia is an important source of the exchange rate earnings. Tourism can affect the exchange rate by visiting a country. Since 
tourism is one of main foreign exchange reserves in Indonesia, it is important to stabilize the real effective exchange rate for the internal and external balance of the economy.

The forecast variance decomposition at a 20-Steps-Ahead forecast horizon. The results do not support the TLG hypothesis. There is no instantaneous effect from tourism to economic growth. In Model 3, the results suggested that an innovation to real GDP explains a greater percentage of its own variation. $61 \%$ of the variance of real GDP are generated by its own innovations, $32 \%$ is generated by the impact of the real effective exchange rate in the long-run and only $7 \%$ by tourist arrivals. Model 4 showed that $89 \%$ of the variance of real GDP are generated by its own innovations and only $2.7 \%$ by those of tourist arrivals and $8.5 \%$ by those of real effective exchange rate.

Similar to real GDP, tourist arrivals explain a relatively greater percentage of its variance on future variation with $77 \%$ and the impact of real effective exchange rate increases monotonically about $19 \%$ in the long run. Contrary to this, in Model 4 showed that the impact of real GDP and real effective exchange rate on the tourist arrivals is rather strong generating $29 \%$ by real GDP and $33 \%$ by real effective exchange rate in the long run.

Furthermore, the variance of the real effective exchange rate, after 20 periods, is exclusively generated by its own innovation with $75 \%$. The impact of tourist arrivals on real effective exchange rate increases about $15 \%$ in the long run. While in Model 4 showed that the variance of the real effective exchange rate is affected strongly by the real GDP and tourist arrivals. The effects after 20 periods from real GDP to the real effective exchange rate is about $51 \%$, tourist arrivals generate $22 \%$ of the variance of the real effective exchange rate, while only $27 \%$ the variance of the real effective exchange rate is exclusively generated by its own innovations.

The evidence of impulse response functions indicates that the real GDP has a positive response to its own shock that is stronger than to the shock of tourist arrivals and the real effective exchange rate. The impulse response of tourist arrivals fluctuates in a pattern over time to its own shock and shocks to real GDP and real effective exchange rate. A shock to the real effective exchange rate has a positive impact on tourist arrivals, although its effects are negligible initially but grow steadily over time. In Model 3, a shock to the real GDP has an impact on the shock of the real effective exchange rate. Although the shocks of the real GDP are quite large in the first 10 periods, they decrease from then through the end of period twenty. the response of the real effective exchange rate is initially stronger to its own shocks than to shocks to other variables but this condition lasts only until quarter 7 . In the end of the period, all of the variables have the same share portion of impact on the real effective exchange rates. While in Model 4, a shock to the tourist arrivals has an impact on the shock of the real effective exchange rate. The effects are stronger than the real effective exchange rate to its own shocks and grow from quarter 6 until the last quarter in the period 20.

\section{CONCLUSION}

This paper empirically tested the validity of the Tourism-Led Growth (TLG) hypothesis in the case of Indonesia by using tests for co-integration, ECM, and conditional Granger Causality. Using the quarterly data for the variables real GDP, international tourist arrivals, and the real affective exchange rate from 2000:Q1-2014:Q4, the cointegration between tourism and real GDP was found to exist in Indonesia in the long run. However, unlike many previous research studies which found a causal relationship (unidirectional or bidirectional) in the short-run, the causality test did not support the TLG hypothesis in the case of Indonesia. The direction of the relationship is unidirectional, that is, output-led tourism. Tourism is strongly affected by economic expansion. However, tourism appears to have some effects on the real effective exchange rate in Indonesia. The greater the number of tourists who visit the country, the greater the number of Indonesia rupiahs to one foreign currency unit (Model 4). 
This is in line with the fact that tourism is already a significant source of foreign exchange revenue for Indonesia. Even though this present study has different results from Nizar (2015), this study provides additional empirical evidence on the impact of tourism on the economy in the case of Indonesia.

\section{POLICY IMPLICATION}

Indonesia's tourism destinations are very much dependent on the growing domestic market, but the fact that the international market in tourism is one of the major resources of the foreign exchange reserves in Indonesia cannot be denied. It is recommended for policymakers to formulate the best strategy to attract more international visitors to Indonesia in order to increase the role of the international markets for increasing foreign exchange reserves and to accelerate the contribution of tourism to the GDP. In terms of tourism planning policy, because the tourism is complex, the government needs to create a comprehensive tourism planning policy that would consider how to integrate the decisions on the tourism related matters such as the tourism budget, approval of private tourism projects, and the scale of the worldwide promotion for diversification Indonesia's tourism source markets. Moreover, the results of this research indicate that the government of Indonesia should focus not only on tourism promotions but also the effectiveness of cluster approach for strengthening the differentiation of tourism products, which requires careful planning.

Lastly, these different results obtained in this study from the expectation that tourism would lead growth in Indonesia may be dependent on factors in the research itself such as the variables and statistical techniques employed. This study used international tourist arrivals as the proxy for tourism, but Indonesia's tourism destinations are very much dependent on the growing domestic market, because of the lack of available data, it was not possible to investigate that variable. However, if it is possible, future research can investigate the role of domestic tourists as the proxy for tourism expansion.

Since this research has different results than Nizar (2015) in the case of Indonesia, in order to ensure more understanding the impact of tourism in Indonesia, it is recommended for future studies to investigate tourism at the regional economic levels (province and regency). Furthermore, since this study only tested tourism and the real effective exchange rate as the main driving forces enhancing economic growth, further investigation should include other economic macroeconomic variables, such as export, trade openness, and human capital as well as use other methodologies for the causality test to support extra meaningful and substantive conclusions.

Finally, in the future studies, researchers may want to compare multiple countries, especially in the South East Asia region which have similar characteristics using above variables as intervening factors between economic growth and tourism expansion and to enable governments to draw more concrete conclusions. If TLG theory can be shown to be correct, it would be benefit for those countries and also provide for sustainable economies.

\section{REFERENCES}

Adams, B., \& Parmenter, B. (1999). General Equilibrium Models in Valuing Tourism: Method and Technique. Canberra: Bureau of Tourism Research, 3-12.

Akinboade, O. A., \& Braimoh, L. A. (2010). International Tourism and Economic Development in South Africa: A Granger Causality Test. International Journal of Tourism Research, 12: 149-163.

Asteriou, D., \& Hall, S. G. (2011). Applied Econometrics. London: Palgrave Macmillan. 
Balaguer, J., \& Cantavella-Jordá, M. (2002). Tourism as A Long-Run Economic Growth Factor: The Spanish Case. Applied Economics, 34(7): 877-884.

Belloumi, M. (2010). The Relationship Between Tourism Receipt, Real Effective Exchange Rate and Economic Growth in Tunisia. International Journal of Tourism Research, 12(5): 550-560.

Bruegel. (2016, March). Real Effective Exchange Rate for 178 Countries: a new Database [Data file]. Retrieved May, 9, 2016, from http://bruegel.org/wpcontent/ uploads/2015/06/REER_database_ver16Mar2016.xls

Copeland, B.R. (1991). Tourism, welfare, and de-industrialization in a small open economy. Econometrica, 58: 515-29.

Cortéz-Jiménez, I., Pulina, M., Prunera, C. R. i., \& Artis, M. (2009, October). Tourism and Exports as a Means of Growth. Retrieved May, 2, 2016, from http:// www.ub.edu/irea/working_papers/2009/200910.pdf

Dimitri, I \& Debbage, K. G. (1998). The Economic Geography of the Tourist Industry. London: Routledge.

Dolado, J.J., \& Lütkepohl, H. (1996). Making Wald Tests Work for Cointegrated VAR System. Econometrics Reviews, 15(4): 369-386.

Dritsakis, N. (2004). Touris a Long-run Economic Growth Factor: An Empirical Investigation for Greece Using Causality Analysis. Tourism Economics, 10(3), 305-316.

Enders, W. (2010). Applied Econometric Time Series. United States of America: Wiley.

Gunduz, L., \& Hatemi-JA. (2005). Is the Tourism-led Growth Hypothesis Valid for Turkey?, Applied Economics Letters 12: 499-504.

ILO. (2009, December). Implications of the Global Economic Crisis for Tourism Employment: Case Study for Indonesia [Report of The Job Opportunities for Youth (JOY) Project]. Retrieved June 19, 2016, from http://www.ilo.org/ wcmsp5/groups/public/@asia/@ro-bangkok/@ilojakarta/documents/publication/wcms 122154.pdf_2XHdGuN1A

Katircioğlu, S. T. (2011). Tourism and Growth in Singapore: New Extension from Bounds Test to Level Relationships and Conditional Granger Causality Test. The Singapore Economic Review, 58(3): 441-453.

Kim, H. J., Chen, M-H., \& Jang, SC. (2005). Tourism Expansion and Economic Development: The Case of Taiwan. Torism Management, 27(5), 925-933.

Kirchgässner, G., Wolters, J., \& Hassler, U. (2013). Introduction to Modern Time Series Analysis. Berlin: Springer Heidelberg.

Lean, H. H., \& Tang, C. F. (2010). Is the Tourism-led Growth Hypothesis Stable for Malaysia? A Note. International Journal of Tourism Research, 12(4). 375-378.

Lorde, T., Francis, B, \& Drakes, L. (2011). Tourism Sevice Exports and Economic Growth in Barbados. The International Trade Journal, 25(2), 205-232. 
Lumaksono, A. (2011). Dampak Ekonomi Pariwisata International Pada Perekonomian Indonesia: Suatu Pendekatan Ekonometrika dan Analisis Input-Output [The Economic Impact of International Tourism in Indonesian Economy: An Econometric and InputOutput Analysis Approach]. Unpublished doctoral dissertation, Institut Pertanian Bogor, Bogor, West Java, Indonesia.

Ministry of Tourism. (January, 2016). Laporan Kinerja Kementerian Pariwisata Tahun 2014 [Performance Report 2014 Ministry of Tourism] Retrieved January, 28, 2015, from http://www.kemenpar.go.id/userfiles/file/LAPORAN\%20KINERJA\%20KEMENTERIA N\%20PARIWISATA\%20TAHUN\%202014\%20v4.pdf

Ministry of Tourism. (January, 2016). Ranking Devisa Pariwisata terhadap Komoditas Ekspor Lainnya [Ranking of the Tourism to Other Commodities Exchange Export] Retrieved January, 28, 2015, from http://www.kemenpar.go.id/userfiles/Ranking\% 20pariwisata\%202014\%20final(1).pdf

Nizar, M. A. (July, 2015). Tourism Effect on Economic Growth in Indonesia. Retrieved January, 28, 2016, from https://mpra.ub.unimuenchen.de/id/eprint/65628

Oh, C-O. (2005). The Contribution of Tourism Development to Economic Growth in the Korean Economy. Tourism Management, 26: 39-44.

Pablo-Romero, M., \& Molina, J. A. (2013). Tourism and Economic Growth: A Review of Empirical Literature. Tourism Management Perspective, 8: 28-41.

Pratiwi, M. E. (2010). Indonesia Forestry Export and Its Economic Growth: Cointegration and Error Correction Models. Unpublished master's theses, Uni Universitas Gadjah Mada, Jogyakarta, D.I Jogyakarta, Indonesia.

Statistic Indonesia. (Agustus, 2015) Statistik 70 Tahun Indonesia Merdeka [Statistics of 70th Indonesia Independence]. Retrieved April, 24, 2016, from https://www.bps.go.id/ index.php/publikasi/1053

Statistic Indonesia. (February, 2015). Quarterly Gross Domestics Bruto at 2000 Constant Market Price by Industrial Origin (Billion Rupiahs), 2000-2014 [Data file]. Retrieved March, 20, 2016, from http://www.bps.go.id/linkTabelStatis/view/id/1206

Statistic Indonesia. Kunjungan Wisatawan Mancanegara 2008 [International Visitor Arrival Statistics 2008]. Retrieved April, 12, 2016, from https://www.bps.go.id/index.php/ publikasi/3626

Statistic Indonesia. Number of Foreign Visitor Arrivals per Month by Port of Entry, 20082016 [Data file]. Retrieved January, 25, 2016, from http://www.bps.go.id/linkTable Dinamis/view/id/807

Tang, C. F., \& Abosedra, S. (2016). Tourism and Growth in Lebanon: New Evidence from Bootstrap Simulation and Rolling Causality Approaches. Empirical Economics, 50(2): 679-696.

Tang, C.F. (2011). Is Tourism-led Growth Hypothesis Valid for Malaysia? A View from Disaggregated Tourism Markets. International Journal of Tourism Research, 13(1): 97 101. 
Tang, C-H., \& Jang, SooCheong (2009). The Tourism-economy Causality in the United States: A Sub-Industry Level Examination. Tourism Management, 30(4): 553-558.

Toda H.Y., \& Yamamoto, T. (1995). Statistical Inference in Vector Autoregressions with Possibly Integrated Processes. Journal of Econometrics, 66(1-2): 225-250.

United Nation Environment Programme (UNEP). (n.d.). Negative Economic Impacts of Tourism. Retrieved May, 2, 2016 from http://www.unep.org/resourceefficiency/ Business/SectoralActivities/Tourism/FactsandFiguresaboutTourism/ImpactsofTourism/E conomicImpactsofTourism/NegativeEconomicImpactsofTourism/tabid/78784/Default.as $\mathrm{px}$

United Nations (UN). (February, 10, 2010). The Contribution of Tourism on Trade and Development [United Nations Conference on Trade and Development]. Retrieved May, 2, 2016, from http://unctad.org/en/Docs/cid8_en.pdf

UNWTO. (2015, April). World Tourism Barometer [Press Release]. Retrieved December 24, 2015, from http://tourlib.net/wto/UNWTO_Barometer_2015_02.pdf

UNWTO. (2015, January). World Tourism Barometer [Press Release]. Retrieved December 24, 2015, from http://dtxtq4w60xqpw.cloudfront.net/sites/all/files/pdf/unwto barom15_01_january_excerpt_1.pdf

UNWTO. (2016). Why Tourism?. Retrieved January, 28, 2016, from http://www2.unwto.org/ content/why-tourism

WTTC. (2015, May). Indonesia Benchmarking Report 2015. Retrieved April, 22, 2015 from http://www.wttc.org/research/economic-research/benchmarkreports/countryresults/\#undefined

Yoeti, O.A. (2008). Ekonomi Pariwisata Introduksi, Informasi, dan Aplikasi [Introduction of Tourism Economics, Information, and Application]. Jakarta: Penerbit Buku Kompas. 